\title{
EDITORIAL
}

\section{How Are We Doing?}

A s members of the ASMS, you probably wonder how your society journal is doing with respect to other journals. A partial answer came recently to you in an email from Springer, our publisher, indicating our 2011 Impact Factor is 4.002 (Thomson Reuters Journal Citation Reports ${ }^{\circledR}$ 2011), a new record for us. For the last 4 years JASMS has seen the following Impact-Factor trend:

\begin{tabular}{ccc}
\hline Year & Impact Factor & Citations \\
2011 & 4.002 & 8794 \\
2010 & 3.830 & 7900 \\
2009 & 3.391 & 7329 \\
2008 & 3.181 & 6075 \\
\hline
\end{tabular}

Breaking the 4.0 barrier is a landmark for JASMS. The journal has come close in the past, but we now hope that the recent growth in ranking can be sustained.

Although the impact factor is not the only and may not even be the best way to rank a journal, it does have the advantage of the simplicity of a single number. It works by measuring how many citations in a given year, say 2011, were made for papers published in the previous 2 years (i.e., 2010 and 2009). The ranking takes on more meaning when journals are compared, especially those in a given category. With respect to other analytical chemistry journals (Table 1), JASMS is number five for journals that publish principally research papers (I removed from the comparison those journals that publish mainly reviews because these articles are usually cited more heavily than research articles).

Another appropriate comparison is with spectroscopy journals, another category used by Thomson Reuters. Here, $J A S M S$ ranks no. 4 , but the three higher ranked journals are principally review journals (Table 2).

To provide additional perspective on impact for journals like JASMS, I created a new category of journals, "Methods." Combining the Thomson Reuters categories of
"Chemistry-Analytical" and "Spectroscopy" and looking at the top 60 cited journals, I classified 48 as "method journals" (i.e., those covering MS, NMR, chromatography, sensors, optical spectroscopy). To make a fair comparison, I excluded review and general analytical journals (e.g., MSR, Anal Chem, Analyst, etc.). The results show that JASMS ranks third in this category. In 2009, JASMS ranked fourth. Included in the comparison are the other mass spectrometry journals that publish principally research articles (Table 3).

Journals, like researchers, can be ranked in terms of an h-index, a controversial indicator that also has appeal as a single number. It is the number of papers published that have that number of total citations. For example, a researcher's h-index of 60 means that 60 of his/her papers have been cited at least 60 times. As an aside, leading chemists have h-factors of greater than 100. I chose to determine the h-factor of JASMS in comparison with other MS journals over a period of 5 years (20072011) by searching with Scopus for a given title and sorting the articles according to number of citations. The list allows one to locate that article whose number order is equal to the number of citations (Table 4). One complaint about $\mathrm{h}$-indices is that to achieve a high value, you must publish a large number of articles. The same complaint is true for a journal comparison. Therefore, I restricted the comparison to MS journals despite the differences in the fractional amounts of content published by those journals, ranging from $5 \%$ to $40 \%$.

I included in Table 4 a relatively new measure called the SJR indicator, a size-independent metric aimed at measuring the current "average prestige per paper" of journals. The indicator counts, more heavily, cites from higher cited journals than lower cited ones on a citation time window of 3 years, taking its citation data from Scopus. This indicator also shows that the impact of JASMS is greater than that of other MS journals. (SCImago (2007). SJR-SCImago Journal and 
Table 1. Comparison with Analytical Chemistry Journals (from ISI)

\begin{tabular}{|c|c|c|c|}
\hline Journal title & No. of cites & 2011 Impact Factor & 5-Year Impact Factor \\
\hline Anal Chem & 95262 & 5.856 & 5.983 \\
\hline Biosens Bioelectron & 20029 & 5.602 & 5.637 \\
\hline Anal Chim Acta & 38343 & 4.555 & 4.144 \\
\hline$J$ Chromatogr A & 60179 & 4.531 & 4.362 \\
\hline Analyst & 14243 & 4.230 & 4.119 \\
\hline$J A S M S$ & 8794 & 4.002 & 3.746 \\
\hline
\end{tabular}

Table 2. Comparison with Spectroscopy Journals

\begin{tabular}{lccc}
\hline \multicolumn{1}{c}{ Journal title } & 2011 Cites & Impact Factor & 5-Year Impact Factor \\
\hline Mass Spectrom Rev & 3994 & 10.461 & 11.676 \\
Annu Rev Anal Chem & 876 & 9.048 & 11.806 \\
Prog Nucl Mag Res Sp & 1765 & 5.214 & 6.296 \\
JASMS & 8794 & 4.002 & 3.746 \\
\hline
\end{tabular}

Table 3. Comparison with "Methods" Journals

\begin{tabular}{lcccc}
\hline \multicolumn{1}{c}{ Journal title } & $\begin{array}{c}\text { 2011 Impact } \\
\text { Factor }\end{array}$ & $\begin{array}{c}\text { 5-Year } \\
\text { Impact } \\
\text { Factor }\end{array}$ & $\begin{array}{c}\text { Number of } \\
\text { articles (2011) }\end{array}$ & $\begin{array}{c}\text { Number } \\
\text { of cites }\end{array}$ \\
\hline $\begin{array}{l}\text { Biosensors/ } \\
\quad \text { Bioelectronics }\end{array}$ & 5.602 & 5.637 & 704 & 20,029 \\
J Chromatog A & 4.531 & 4.362 & 1104 & 60,179 \\
JASMS & 4.002 & 3.746 & 228 & 8794 \\
J Mass Spectrometry & 3.268 & 3.301 & 143 & 5549 \\
Rapid Commun MS & 2.790 & 2.782 & 426 & 13,453 \\
Int J Mass Spectrom & 2.549 & 2.241 & 297 & 7305 \\
European JMS & 1.207 & 1.249 & 50 & 566 \\
\hline
\end{tabular}

Country Rank. Retrieved August 30, 2012, from http:// www.scimagojr.com).

Credit for much of our progress is due to our authors who show a commitment to JASMS by submitting strong papers. Credit also goes to our associate editors and reviewers who
Table 4. JASMS h-factor and Those of Other MS Journals (as of 9/7/12)

\begin{tabular}{lccccccc}
\hline Journal & h-Factor & $\begin{array}{c}\text { Number } \\
\text { of } \\
\text { articles }\end{array}$ & $\begin{array}{c}\% \text { of } \\
\text { Total } \\
\text { content }\end{array}$ & $\begin{array}{c}\% \text { 5 cites } \\
\text { or more }\end{array}$ & $\begin{array}{c}\% \text { cites } \\
10 \text { or more }\end{array}$ & $\begin{array}{c}\% \text { cites } \\
\text { or more }\end{array}$ & $\begin{array}{c}\text { SJR } \\
\text { Ranking } \\
\text { (5-year } \\
\text { average) }\end{array}$ \\
\hline JASMS & 38 & 1190 & $22 \%$ & $1.5 \%$ & $35 \%$ & $77 \%$ & 0.394 \\
RCMS & 37 & 2168 & $40 \%$ & $0.5 \%$ & $28 \%$ & $69 \%$ & 0.244 \\
$J M S$ & 29 & 633 & $12 \%$ & $1.5 \%$ & $24 \%$ & $64 \%$ & 0.293 \\
IJMS & 28 & 1155 & $21 \%$ & $0.8 \%$ & $20 \%$ & $63 \%$ & 0.193 \\
EJMS & 14 & 263 & $05 \%$ & $0.7 \%$ & $9 \%$ & $38 \%$ & 0.118 \\
Anal & 83 & 6272 & na & $4.9 \%$ & nd & nd & 0.568 \\
\multicolumn{1}{c}{ Chem } & & & & & & & \\
\hline
\end{tabular}

na $=$ not applicable

nd $=$ not determined

demonstrate a strong sense of pride in the journal and apply high standards in article review. The journal's special features, particularly critical insights and focus sections, add to the utility of JASMS and increase its value to you, the MS community. I thank the associate editors, authors, and reviewers for their commitment and support. Thanks are also owed to the ASMS and its board of directors and professional organizers who have supported the journal for nearly a quarter of a century, and to managing editor Joyce Neff, who has worked tirelessly for JASMS for 15 years.

Part of our progress is due to the "new look" of JASMS resulting from changes made in collaboration with our new publisher, Springer. We have used cover art for many years now, but our new cover, while still in "JASMS red," is more attractive and interesting, has a more uniform appearance from month to month, and now draws attention to articles contained in the journal. The editor now orders the articles, putting articles of related subjects together so they can be browsed rapidly and read comparatively. We hope these improvements in rankings and layout encourage authors to use $J A S M S$ as a venue for publication.

Michael L. Gross, Editor

Washington University in St Louis

e-mail:mgross@wustl.edu 